\title{
Moral Destabilisation or Revivification: The Trend of Religion-Based Social Capital Following 9/11
}

\author{
Durmus A. Yuksek \\ Turkish Military Academy, Ankara, Turkey \\ durmusaliyuksek@gmail.com
}

\begin{abstract}
Although different aspects of the 9/11 terrorist attacks have been widely studied, few researchers have attempted to understand both its religious and social aspects. In this context, considering the declining trend of social capital in the United States, whether $9 / 11$ has become a window of opportunity for civic renewal and whether such renewal has been short-lived or long-lived become highly important to examine. To address these questions, this study examines whether the level of social capital in the American society changed from 2000 to 2006 and whether religious traditions had different effects on their members' social capital levels following 9/11.
\end{abstract}

\section{Keywords}

Social capital - 9/11 - religion - trust - civic engagement

\section{$1 \quad$ Introduction}

Terrorist attacks on September 11, 2001 to the World Trade Center and Pentagon have been one of the most dramatic events in the 21st century for both the United States and the World. The efforts to damage the image of the United States, which has been the only super power in the 21st century by unexpected attacks on its own soil, have led to significant political, economic, and social changes all around the world (Henshall and Morgan 2005). While the attacks have been seen against the social, political, and economic integrity of the United States and solidarity of American society, due to the terrorists' Muslim origin, the attacks have gained a religious meaning (Klandermans et al. 2008). 
Since the United States is known as a Caucasian/Christian country (Kaya 2007), the war launched against Afghanistan and Iraq following 9/11 has led to the specifications that the war is against Islam not against terrorism, a "religious war" (Hodgson 2005). Huntington's (1993) idea of "clash of civilizations," which he assumes between possibly the most opposite regions in many respects, the West and the Islamic World, has won significance in the wake of 9/11. In the meantime, statements of some religious and political leaders intensified this conflict (Johnson 2006; Kaya 2007).

The United States has been widely known as a country of diversities. Not only known for its diversities of nations, races, and colors, it has also been widely acknowledged that "the United States has been the most God-believing and religion-adhering, fundamentalist, and religiously traditional country in Christendom, as well as the most religiously fecund country where more new religions have been born than in any other society" (Putnam 2000: 65). Following this argument, even though the $9 / 11$ terrorist attacks caused significant social and political damage in the U.s., the American response to the attacks has varied depending on the above-mentioned diversities. The general response has been the increasing levels of solidarity, civic conscience, trust, and integrity among American citizens (Putnam 2002; Schmierbach et al. 2005; Sander and Putnam 2010). Also, with the increasing levels of solidarity and civic conscience, social capital has tended to increase (Putnam 2002; Schmierbach et al. 2005; Sander and Putnam 2010).

As an increasingly popularized concept within sociology in recent years, social capital refers to "connections among individuals - social networks and the norms of reciprocity and trustworthiness that arise from them" (Putnam 2000: 19). According to Putnam, engaging in civic organizations and voluntary activities provide individuals social contacts and resources acquired through them, and these contacts "facilitate coordination and communication, amplify reputations, and thus allow dilemmas of collective action to be resolved" (Putnam 1995: 67). Therefore, participation in civic organizations and voluntary activities are primary forms of social capital. Also, social trust - trust in one another - is another important form of social capital. People who trust their fellow citizens volunteer more often, participate more in civic activities, and display many other forms of civic virtue (Putnam 2000: 145). In this sense, people who trust others and participate more often in civic and volunteer activities accumulate more social capital and this facilitates their lives within their communities and provides valuable benefits.

Despite its devastating effects on American society, Putnam (2002) sees the terrorist attacks on $9 / 11$ as a window of opportunity against the ongoing decline of social capital since 196os. Immediately after $9 / 11$, Putnam (2002) found that 
Americans trusted more in one another, expressed confidence more, and participated more in civic activities. However, whether the immediate increases in attitudes (e.g., trust in one another and civic mindedness) and behaviors (e.g., civic engagement) were short-lived or long-lived, and whether the changes in attitudes would lead to changes in behaviors were important questions that need to be answered.

In addition, research that has addressed the assertion that the level of social capital in the U.s. has increased following 9/11 considered American society as a whole without considering the different religious traditions' perspectives (Putnam 2002; Schmierbach et al. 2005; Sander and Putnam 2010). However, especially due to the diversity of religious traditions and diverse level of religiosity among Americans, the notions of unity and integrity and in accordance with that the levels of social capital have differed among Americans, especially after $9 / 11$, considering the terrorists' Muslim origin. In this sense, research focusing on how different religious traditions responded to the attacks and how this affected their members' social capital levels represent an important effort in addressing this research gap. The aim of this study, therefore, is to address this gap by focusing on the religious traditions in the U.s. - Conservative Protestantism, Mainline Protestantism, and Catholicism, on how these different religious traditions' perspectives affected their members' social capital levels following $9 / 11$, and on whether the asserted increases in social capital immediately after $9 / 11$ in the forms of attitudes and behaviors had been shortlived or long-lived.

To achieve this aim, this study uses the 2000 Social Capital Community Benchmark Survey (SCCBS) and the 2006 Social Capital Community Survey (scCs), which provide measures of various manifestations of social capital in American society.

\section{Conceptual Arguments and Theoretical Framework}

\subsection{What Has Changed in the U.s. after $9 / 11$ ?}

The catastrophic terrorist attacks on September 11, 2001 to the World Trade Center in New York and the Pentagon have changed the social, economic, and political balance of not only the United States, but also the whole world. It was received with astonishment by both Americans and the citizens of other countries that terrorists targeted the United States on its own soil. It has been perceived that the unexpected assaults took aim at not only the political, economic, and social integrity of American society, but also the religious integrity since all the terrorists had Muslim identities and connections with the terrorist 
group, Al-Qaeda (Henshall and Morgan 2005). These developments have led to significant and observable changes in American society. These changes have demonstrated themselves most notably as governmental legislations, such as Patriot Act, Enhanced Border Security and Visa Entry Reform Act, Aviation and Transportation Security Act, etc. Many studies have been conducted to observe and understand the effects of 9/11 on American society and individuals' lives (Alexander 2004; Henshall and Morgan 2005; Schmierbach et al. 2005; Beyerlein and Sikkink 2008); however, in the context of the declining trend of social capital within American society since 196os and of whether 9/11 has changed this trend, Putnam's studies come forward (Putnam 1995; Putnam 2000; Putnam 2002; Sander and Putnam 2010).

Despite the devastating effects of $9 / 11$ on American society, Putnam (2002) sees this tragedy as a window of opportunity for civic renewal that occurs once or twice a century. Putnam argues that civic engagement had been on a significant decline in the United States, and Americans grew ever less connected with one another over the last decades of the 2oth century. He said: "we voted less, joined less, gave less, trusted less, invested less time in public affairs, and engaged less with our friends, our neighbors and even our families. Our 'we' steadily shriveled" (Putnam 2002: 20). Many studies support Putnam's opinions about the steady decrease of solidarity of Americans. For instance, in the 1960s more than half of Americans said that they trusted others; today this ratio decreased to less than 30 percent (Sander and Putnam 2010). In comparison with their grandchildren, Americans born before 1930 were twice as trusting, 75 percent more likely to vote, and more than twice as likely to take part in community projects (Sander and Putnam 2010). Voting in presidential elections diminished gradually from 63 percent in the 1960 election to 49 percent in 1996, which was the lowest level since 1924 (Verba et al. 1997). According to Sander and Putnam (2010), this tendency of decline in civic engagement in America can be slowed down by an increase in youth volunteering, and the increase in youth volunteering can be facilitated by national crisis, such as wars, economic depressions, or natural disasters. Therefore, 9/11 might have been a stimulating effect on American society.

As Sander and Putnam (2010) asserted, after 9/11 civic engagement in the United States began to increase (Putnam 2002; Sander and Putnam 2010). Alexander (2004) asserts that the terrorist attacks on 9/11 could not achieve their objectives, which were to create political and moral instability and to achieve social instability. In contrast, the terrorist attacks produced exactly the opposite effect on society, "rather than moral destabilisation there was revivification" (Alexander 2004: 103). Since the attacks towards the American 
symbols and beliefs on America's own soil created an idealization of everything American, this provided an uprising in the hearts and souls of all Americans. Despite the pessimistic results of the attacks, the levels of solidarity, trust, patriotism, charity, civic engagement, and faith in people have increased after the attacks (Schmierbach et al. 2005).

Putnam and his colleagues conducted two nationwide surveys of civic attitudes and behaviors before and right after 9/11 in 2000 and 2001. Results of these surveys showed that $9 / 11$ had destructive immediate effects, but these effects disappeared quickly and people returned to their normal lives (Putnam 2002). Putnam (2002) didn't find any clear change in people's religiosity and church attendance after the tragedy, but when compared to the results of the 2000 survey, the results of the 2001 survey showed that there was an increase in political consciousness and engagement, in trust in government, police, and one another and in interest in politics (Putnam 2002). According to Putnam (2002), people expressed confidence and cooperated more with each other in the following days of 9/11. As Alexander (2004:100) states:

Before 9/11, America had been fractured by social cleavages, by the normal incivilities attendant on social complexity, and even, on occasion, by unspeakable hostilities. After $9 / 11$, the national community experienced and interpreted itself as united by feeling, marked by the living kindness displayed among persons who once only had been friends, and by the civility and solicitude among those who once merely had been strangers.

However, in the context of the significant decline of trust and civic engagement in American society since 1960s, Putnam (2002) was curious about whether $9 / 11$ was "a period that puts a full stop to one era and opens a new, more community-minded chapters in our history," or it was "merely a comma, a brief pause during which we looked up for a moment and then returned to our solitary pursuits?" (Putnam 2003: 13). Also, he was anxious whether the immediate changes in attitudes such as trust and civic consciousness would lead to long-term changes in behaviors such as civic engagement and voluntarism - an attitude-behavior dilemma. This question was an important one for Putnam because the answer would show if the blossom of civicmindedness after $9 / 11$ would be short-lived or long-lived. In this regard, the first question that this study attempts to answer is: in the context of the declining trend of social capital in American society since 196os, has social capital increased following $9 / 11$, and if so, has this increase been short-lived or long-lived? 


\subsection{Religion and Social Capital}

Putnam (2002) asserted that civic engagement in the United States increased following $9 / 11$, and many social scientists associate civic engagement with social capital (Putnam 2000; Fukuyama 2001; Putnam 2002; Uslaner 2002; Wuthnow 2002; Sander and Putnam 2010). Even though social capital is widely known as a concept with positive effects on society and individuals, considering its individual and community-level benefits, social capital might actually have both positive and negative effects on society and individuals. For instance, research shows that social capital is positively related to the happiness and health of people, economic productivity and government's responsiveness, and honesty (Ferlander 2007; Sander and Putnam 2010; Yeary et al. 2012). However, research also shows that strong in-group ties (high level of social capital within a group) that connect members of a group might enable them to be successful in their economic initiatives while excluding other groups from economic opportunities (Portes and Landolt 1998), constricting others to a limited network structure (Beyerlein and Hipp 2006), and even causing racial inequality and residential segregation (Blanchard 2007). In sum, it can be asserted that social capital has positive outcomes for individuals in the form of in-group favoritism and has negative outcomes in the form of out-group antagonism.

Religion, in this respect, plays an important role as a provider of social capital to its practitioners by shaping their values, norms, and preferences, linking them to each other, developing community cohesion, and thus causing in-group favoritism and out-group antagonism. Despite the consensus on the relationship between social capital and religion, the differentiating orientations of the religious traditions make it complicated for researchers to observe the diverse levels of social capital of the members of different religious groups. Therefore, in the intersection of social capital and religion, we must first consider the various religious orientations and these orientations' perspectives towards society and social events.

Despite the religious diversity in the United States most Americans belong to one of the two main religious traditions: Protestantism and Catholicism. In the 2000 General Social Survey (GSS), 54 percent of the respondents defined themselves as Protestant and 24.1 percent of the respondents defined themselves as Catholic. In the 2014 GSs, these percentages were 44.3 and 23.9 respectively. Catholics compared to Protestants are more convergent in terms of denominations; therefore it is assumed to be easier for researchers to predict their reactions to social events. However, numerous Protestant churches are assumed to make it more difficult to predict their reactions to social events since their reactions tend to change according to their religious orientations. Therefore, it is necessary to categorize Protestant denominations 
to better understand their different perspectives. Steensland et al. (2000) suggest a framework that categorizes Protestantism into two distinct groups: Conservative Protestantism and Mainline Protestantism. Steensland et al. (2000: 293-294) argue that in white Protestantism, ${ }^{1}$ Mainline denominations "have typically emphasized an accommodating stance toward modernity, a proactive view on issues of social and economic justice, and pluralism in their tolerance of varied individual beliefs." However, Conservative Protestantism "have typically sough more separation from the broader culture, emphasized missionary activity and individual conversion, and taught strict adherence to particular religious doctrines." In other words, Conservative Protestants compared to Mainline Protestants put more importance on the sacred church life than the profane civic life, see Bible as the ultimate religious authority in their decisions, and are more likely to believe in religious exclusivism - believing the superiority of one belief system and claiming that all others are mistaken (Rhodes 2012). Catholics, by the way, share similar characteristics with Mainline Protestants rather than Conservative Protestants and therefore differ significantly from them in mobilizing their members for civic action in communities (Beyerlein and Hipp 2006; Blanchard 2007). Also, as Lehrer (2004) states, the behavior of Catholics resembles to the Mainline Protestant pattern in most domains of family life.

Prior studies (Woodberry and Smith 1998; Blanchard et al. 2008) identified three important subcultures within the Conservative Protestant tradition: Fundamentalist, Evangelical, and Pentecostal traditions. In general, there are not any clear differences between Fundamentalists and Pentecostals, and they share many theological similarities; but unlike the two other denominations, Evangelicals are more open to secular world and view modern life as an opportunity to get engaged with a broader environment without abandoning their religious values (Massengill 2008). Evangelicals participate in organizations even with non-Evangelicals and promote reform movements aimed toward secular institutions. In this sense, it can be asserted that Evangelicals share similar characteristics with Mainline Protestants and Catholics rather than the other two Conservative Protestant orientations.

Following the differences between Conservative Protestantism and Mainline Protestantism (and Catholicism) and between Evangelicals and the other two

1 Even though black Protestantism is a distinctive religious tradition (Steensland et al. 2000), I follow Edgell, Gerteis, and Hartmann (2006) in their operationalization of Conservative Protestantism by classifying some black Protestant denominations as "conservative" since some of the black Protestant traditions share with the Conservative Protestant subculture characteristics. 
Conservative Protestant traditions, Blanchard (2007) argues that Conservative Protestants (Fundamentalists and Pentecostals but not Evangelicals) are more socially disconnected from the broader community and more introverted and more socially isolated into their own communities when compared to Mainline Protestants and Catholics. Therefore, the social networks of Conservative Protestants provide fewer opportunities for them to enter into civic engagement with the broader community, and therefore they are less likely to develop social capital. Because Mainline Protestants and Catholics (and also Evangelicals within the Conservative Protestant tradition) are more open to get engaged with the broader community, they participate in outgroup activities to establish social ties and enlarge their networks. Thus, they have more opportunities to develop and accumulate social capital (Beyerlein and Hipp 2006). For instance, in his study conducted in the United States and Canada, Uslaner (2002) found that Conservative Protestants were much more likely to spend their time participating in church-based activities than Mainline Protestants. Likewise, Beyerlein and Hipp (2006) examined the relationship between the different religious traditions and the participation rates of their members in civic activities and found that Conservative Protestants were less likely to participate in civic activities and charitable organizations than Mainline Protestants and Catholics. Lastly, Owen and Wagner (2006) found that in Finland, Pentecostals were less likely to be active in out-church volunteerism, while Lutheran national church ${ }^{2}$ members were active in both in-church and out-church volunteerism.

In light of the above arguments, it can be asserted that the different worldviews of Conservative Protestantism, Mainline Protestantism, and Catholicism affect how their members see, understand, and interpret the social world, and how they communicate and contact with others. Especially immediately after hard times such as $9 / 11$, it becomes more important for people to come together, share, and empathize with each other for the process of revivification. In this regard, people's worldviews affected by their religious orientations influence how they use their social networks and accumulate social capital during this process.

After the 9/11 terrorist attacks, the media showed the negative images of Islam and Muslims. Muslims were reflected as irrational, uncivilized, undemocratic, threatening, and Islam was demonized and made to appear antithetical to civilization and Western values (Kaya 2007). This has turned many Americans' negative attitudes into the form of prejudice against the faith of Islam and Muslims. After 9/11, the prejudicial attitudes among Americans

2 A Mainline Protestant denomination. 
against Muslims have been versatile depending on their religious orientations. For instance, a survey conducted shortly after $9 / 11$ showed that Conservative Protestants were more likely to oppose Islam than other Americans (Cimino 2005). A Pew survey showed that 62 percent of Conservative Protestants expressed that Islam was very different from their religion as opposed to 44 percent of non-Conservatives who held this view. Lastly, in a Beliefnet/Ethics and Public Policy survey it was found that 77 percent of Conservative Protestant leaders had an overall negative view of Islam and 70 percent of them thought that Islam is a religion of violence (Cimino 2005). All in all, the worldviews of different religious orientations - Conservative Protestantism, Mainline Protestantism, and Catholicism - affected how people perceived the images of Islam and Muslims and how they contacted with others, not only with Muslims but also with others from different religious traditions - thus using their social networks and accumulating social capital. In this context, it can be argued that 9/11 might have affected individuals' social capital levels and how they accumulated social capital (through connecting with others, enlarging their social networks) differently depending on their religious orientations. This leads us to the second question that this study attempts to answer: how did the worldviews of different religious traditions - Conservative Protestantism, Mainline Protestantism, and Catholicism - affect their members' social capital levels following $9 / 11$ ?

Data and Measures

\subsection{Data}

The data for this study comes from the 2000 Social Capital Community Benchmark Survey (sсCвs) and the 2006 Social Capital Community Survey (scCs). The Saguaro Seminar at the John F. Kennedy School of Government at Harvard University administered the SСсвS in 2000 to measure various manifestations of social capital. The sccs was administered by the same organization in 2006 as a follow-up survey to the sссвS.

Both the SCCBS and the SCCS are household surveys. In 2000, the sСсвS was administered to 29,233 persons, and in 2006, the sCCs was administered to 12,100 persons. The interviews were made by telephone. Respondents were non-institutionalized U.s. residents 18 years of age or older.

\subsection{Dependent Variables}

Despite its popularity, one of the most important weaknesses of the concept of social capital for research is the absence of a consensus on how to measure 
it (Fukuyama 2001). Measuring social capital is difficult, if not impossible to measure directly. Therefore, for empirical purposes the use of proxy indicators is necessary (Collier 2002). Research have applied various indicators of social capital in different contexts. Examples include: trust (Kolankiewicz 1996; Cox and Caldwell 2000; Glaeser et al. 2000), membership (Warde et al. 2003; Wollebaek and Selle 2003), membership and trust (Lappe et al. 1997; Veenstra 2002; Lochner et al. 2003); membership, trust, and norms of reciprocity (Putnam 2000; Skrabski et al. 2003; Staveren 2003), and network resources (Lin 2001; Zhao 2002). For this study, I followed Putnam (2000) and designated two dependent variables that can be used as proxy indicators of social capital: trust as the attitudinal form of social capital and civic engagement as the behavioral form of social capital.

Trust is an index that consists of eight items (see the Appendix) indicating one's level of trust towards others. Answer possibilities are: trust them a lot (3), trust them some (2), trust them only a little (1), and trust them not at all (o). All these items correlate highly and show sufficient reliability (Cronbach's alpha $=.88$ in 2000 and .89 in 2006). I created an additive scale to construct the "trust" dependent variable. Higher scores point to higher levels of trust towards others.

Civic engagement is an index consists of 13 items (see the Appendix). Each item indicates whether the respondent participated in the activity or not. In order to define the civic engagement dependent variable, I added the "yes" responses to the 13 activities for each respondent. All these items correlate highly and show sufficient reliability (Cronbach's alpha $=.71$ in 2000 and .72 in 2006). The total score ranges from $o$ (no activities at all) to 13 (every one of the 13 activities).

The distribution of the civic engagement dependent variable is heavily skewed with many respondents reporting no participation; therefore, oLS regression is inappropriate (Hilbe 2011). Poisson regression and negative binomial regression methods are generally used to model count data. Poisson regression assumes that the dependent variable is not over-dispersed, and the mean and the variance of the dependent variable are equal. The civic engagement dependent variable is characterized by overdispersion ${ }^{3}$ and a large number of zero values. Therefore, I use negative binomial regression for this dependent variable (Land et al. 1996; Hilbe 2011). For the trust dependent variable I use oLs regression method.

3 The estimates of the dispersion coefficients in the output of the negative binomial regression models suggest that the negative binomial model is more appropriate than the Poisson. For the mean and variance of the dependent variables, see Table 1 . 


\subsection{Independent Variable}

The religious preference is the independent variable determined for this study. Religious preference was operationalized using five dichotomous variables for Catholics, Mainline Protestants, Other Religion, ${ }^{4}$ Evangelicals, and Fundamentalists-Pentecostals. ${ }^{5}$ In order to code respondents who defined their religious preference as Protestant, three major studies were used for denominational affiliations (Steensland et al. 2000; Blanchard et al. 2008; Vaaler et al. 2009).

\subsection{Control Variables}

The controls included into the analysis are age, age squared, gender, total household income, race, formal education, region, marital status, current employment status, whether a member of religious community or not, and frequency of attendance to religious services. The measures of age and age squared are relatively straightforward. Total household income was recoded to the midpoint value for each category, ranging from " $\$ 20,000$ or less" to "100,000 or more," then, converted to $\$ 10,000$ units. I converted the income value of 2000 to 2006 dollars to account for inflation. Formal education was measured using seven categories that range from "less than high school" to "graduate or professional degree." I converted these seven categories to years of education that ranges from 10 years of education to 20 years of education. Dummy variables were coded as follows: gender (female $=1$ and male $=0$ ), race (white $=1$ and otherwise $=0$ ), region (northeast $=1$ and otherwise $=0$ ), marital status $($ married $=1$ and not married $=0$ ), employment status ( employed $=1$ and not employed $=0$ ), and membership to a religious community ( member $=1$ and not a member $=0$ ). Lastly, the ordinal scale for the frequency of attendance to religious services ranges from "every week or more often" to "less often than a few times per year." I converted this measure to an interval-level scale by recoding the responses to approximate days attending religious services per year. Descriptive statistics with regard to the dependent variables, independent variable, and control variables are displayed in Table 1.

4 "Other Religion" independent variable includes: "another type of Christian," "Jewish," "some other religion," and "no religion" groups.

5 Within the Conservative Protestant tradition, Fundamentalists and Pentecostals were combined since these two denominations share similar subculture characteristics and substantially differ from the other Conservative Protestant tradition, Evangelicals. 


\begin{tabular}{|c|c|c|c|c|}
\hline Variable Name & $\begin{array}{l}\text { Mean } \\
2000\end{array}$ & 2006 & $\begin{array}{l}\text { Std. Dev. } \\
2000\end{array}$ & 2006 \\
\hline \multicolumn{5}{|l|}{ Dependent Variables } \\
\hline Trust & 16.259 & 17.162 & 4.825 & 4.649 \\
\hline Civic Engagement & 3.097 & 2.482 & 2.5 & 2.595 \\
\hline \multicolumn{5}{|l|}{ Control Variables } \\
\hline Age & $.45^{8}$ & .528 & .164 & .163 \\
\hline Age Squared & .237 & .306 & .165 & .179 \\
\hline Female & .608 & .622 & .488 & .484 \\
\hline Income & 6.678 & $6.15^{8}$ & 4.667 & 4.254 \\
\hline White & .801 & .844 & $\cdot 399$ & .362 \\
\hline Education & 14.33 & 14.514 & 2.872 & 2.913 \\
\hline Northeast & $.15^{1}$ & .211 & $\cdot 35^{8}$ & .408 \\
\hline Married & .536 & .572 & .498 & .494 \\
\hline Employed & .67 & .594 & .47 & .490 \\
\hline Church Mem. & .665 & .688 & .471 & .462 \\
\hline Church Freq. & 29.857 & 31.362 & 22.264 & 22.821 \\
\hline \multicolumn{5}{|l|}{ Independent Variable } \\
\hline Other Religion & .197 & .173 & .398 & .378 \\
\hline Catholic & .255 & .237 & .436 & .425 \\
\hline Mainline Pro. & .39 & .389 & .487 & .487 \\
\hline Conservative Pro. & $.15^{6}$ & .199 & .363 & .399 \\
\hline Fundamental-Pentecostal & .094 & .092 & .293 & .290 \\
\hline Evangelical & .061 & .106 & .24 & .308 \\
\hline
\end{tabular}

Regarding the first research question that this study attempts to answer, which is "in the context of a declining trend of social capital in American society since 1960s, whether social capital increased following $9 / 11$, and if so, whether this increase had been short-lived or long-lived," Table 2 shows the mean and standard deviation scores of the two dependent variables as well as the $t$ and $p$ values indicating whether their values changed from 2000 to 2006. 
TABLE 2 The trend in the levels of trust and civic engagement, 2000-2006

\begin{tabular}{|c|c|c|c|c|c|c|}
\hline & $\begin{array}{l}\text { Mean } \\
2000\end{array}$ & 2006 & $\begin{array}{l}\text { Std. Dev. } \\
2000\end{array}$ & 2006 & $t$ & $p$ \\
\hline Trust & 16.259 & 17.162 & 4.825 & 4.649 & 14.7485 & $<.001$ \\
\hline Civic Engagement & 3.097 & 2.482 & 2.501 & 2.595 & -18.4094 & $<.001$ \\
\hline
\end{tabular}

As can be seen in Table 2 both dependent variables significantly changed from 2000 to 2006 . The level of trust significantly increased from 16.25 in 2000 to 17.16 in 2006 ( $t=14.74 ; p<.001)$, while the level of civic engagement significantly decreased from 3.09 in 2000 to 2.48 in $2006(t=-18.4 ; p<.001)$. It has been asserted that despite the declining trend of social capital in American society since 196os, there were immediate increases in trust in one another and civic engagement following 9/11 (Putnam 2002). However, as these findings show, increase in the level of civic engagement had been short-lived and quickly faded away as the time passed, while increase in the level of trust attitude had been long-lived and did not fade away as the other one did.

Regarding the second research question that this study attempts to answer, which is "how the worldviews of different religious traditions - Conservative Protestantism, Mainline Protestantism, and Catholicism - affected their members' social capital levels following 9/11," Tables 3 through 6 present the regression coefficients of trust (Tables 3 and 4 ) and civic engagement (Tables 5 and 6) dependent variables in 2000 and 2006, respectively. In all these tables eight models were presented. Model 1 of each tests the effect of being a member of Catholic tradition, Models 2 of each tests the effect of being a member of Mainline Protestant tradition, Models 3 of each tests the effect of being a member of Evangelical tradition, and Models 4 of each tests the effect of being a member of Fundamental-Pentecostal tradition, on the levels of trust and civic engagement. Through Models 1-4 of each table, I calculated predicted values of the levels of trust and civic engagement for a 45-year old, white, female, northeastern, married, employed, and church member Catholic (Mainline Protestant, Evangelical, or Fundamental-Pentecostal). For education, income, and church participation frequency variables, I used the mean values to calculate the predicted values. Thus, through Models 1-4 of each table, I could compare the predicted values of the levels of trust and civic engagement of an average member of each religious tradition and observe whether the level of social capital of an average Catholic (Mainline Protestant, Evangelical, or 
Fundamental-Pentecostal) individual decreased or increased from 2000 to 2006.

Additionally, through Models 5-8 of each table, ${ }^{6}$ I tested whether there were significant differences between religious traditions in their effects on trust and civic engagement in 2000 and 2006. In this regard, Model 5 of each table compares being a member of Catholic tradition, Model 6 of each table compares being a member of Mainline Protestant tradition, Model 7 of each table compares being a member of Evangelical tradition, and Model 8 of each table compares being a member of Fundamental-Pentecostal tradition, to being a member of the other religious traditions in their effects on trust and civic engagement.

Regarding the trust attitude, Models 1 through 4 of Table 3 show that all the religious traditions were significantly related to the trust attitude in 2000. In other words, compared to other religious traditions, being a member of Catholic, Mainline Protestant, or Evangelical tradition positively affected one's level of trust towards others. However, being a member of FundamentalistPentecostal tradition, compared to other religious traditions, negatively affected one's level of trust towards others. Looking at the predicted values, we can see that Evangelicals were the most trusting individuals, followed by Mainline Protestants, Catholics, and Fundamentalists-Pentecostals. Besides, Models 5 through 8 of Table 3 show that while Evangelicals trusted more than the other religious traditions, they significantly differed only from the other Conservative Protestant tradition, Fundamentalists-Pentecostals. This means that in terms of trust in 2000, Mainline Protestants, Catholics, and Evangelicals shared similar characteristics without any significant differences from each other, while Fundamentalists-Pentecostals significantly differed from them and trusted less in one another.

In 2006, Models 1 through 4 of Table 4 show that all the religious traditions lost their significant effects on the trust attitude, except for Mainline Protestants. This means that only being a member of Mainline Protestant tradition, compared to other religious traditions, significantly and positively affected one's level of trust towards others. Examining the predicted values, we can see that all the religious traditions increased their level of trust from 2000 to 2006, following the increase in American society shown in Table 2, and Mainline Protestants were the most trusting individuals. However, one

6 In Models 5 through 8 of each Table, the estimates of the control variables were not shown due to space restrictions. 
interesting finding is that Fundamentalists-Pentecostals increased their trust most with almost 1 unit increase. Also, Models 5 through 8 of Table 3 show that only Mainline Protestants significantly differed from FundamentalistsPentecostals in their trust attitude. All the other religious traditions shared similar characteristics in 2006.

TABLE 3 Multiple regression estimates of trust in $2000(n=19,319)$

\begin{tabular}{|c|c|c|c|c|c|c|c|c|}
\hline & \multicolumn{2}{|l|}{ Model 1} & \multicolumn{2}{|l|}{ Model 2} & \multicolumn{2}{|l|}{ Model 3} & \multicolumn{2}{|l|}{ Model 4} \\
\hline & b & SE & b & SE & b & SE & b & $S E$ \\
\hline \multicolumn{9}{|l|}{ Control Var. } \\
\hline Age & $8.321^{* * *}$ & 1.162 & $8.143^{* * *}$ & 1.162 & $8.171^{* * *}$ & 1.161 & $8.456^{* * *}$ & 1.162 \\
\hline Age Squared & $-7.271^{* * *}$ & 1.183 & $-7.184^{* * *}$ & 1.182 & $-7.159^{* * *}$ & 1.182 & $-7 \cdot 422^{* * *}$ & 1.183 \\
\hline Female & .076 & .068 & .062 & .068 & .071 & .068 & .065 & .068 \\
\hline Income & $.057^{* * *}$ & .008 & $.058^{* * *}$ & .008 & $.058^{* * *}$ & .008 & $.057^{* * *}$ & .008 \\
\hline Education & $.177^{* * *}$ & .012 & $.177^{* * *}$ & .012 & $.177^{* * *}$ & .012 & $.172^{* * *}$ & .012 \\
\hline White & $2.502^{* * *}$ & .085 & $2.549^{* * *}$ & .084 & $2.526^{* * *}$ & .084 & $2.514^{* * *}$ & .084 \\
\hline Northeast & $.191^{*}$ & .092 & $.24^{* *}$ & .091 & $.232^{* *}$ & .091 & $.199^{*}$ & .092 \\
\hline Married & $.449^{* * *}$ & .072 & $.438^{* * *}$ & .071 & $.441^{* * *}$ & .071 & $.445^{* * *}$ & .071 \\
\hline Employed & $1.193^{* * *}$ & .082 & $1.194^{* * *}$ & .082 & $1.193^{* * *}$ & .082 & $1.193^{* * *}$ & .082 \\
\hline Church Member & $.401^{* * *}$ & .085 & $.417^{* * *}$ & .085 & $.431^{* * *}$ & .085 & $.42^{* * *}$ & .085 \\
\hline Frequency & $.008^{* * *}$ & .001 & $.009^{* * *}$ & .001 & $.008 * * *$ & .001 & $.009^{* * *}$ & .001 \\
\hline
\end{tabular}

Independent Var.

Catholic

Mainline Pro

Evangelical

Funda-Pente
$.231^{* *} \quad .077$

$$
.184^{* *} \quad .067
$$

$.37^{* *} \quad .136$

$-.517^{* * *} \quad .113$

$.297 \quad 7.524^{* * *}$

$.297 \quad 7.564^{* * *}$

$.2977 .648^{* * *}$

.298

.1100

.1100

.1107

18.21
18.009 
TABLE 3 Multiple regression estimates of trust in 2000 (cont.)

\begin{tabular}{|c|c|c|c|c|c|c|c|c|}
\hline & Model 5 & & Model 6 & & Model 7 & & Model 8 & \\
\hline & $\mathbf{b}$ & SE & b & SE & b & SE & $\mathbf{b}$ & SE \\
\hline Other Religion & $-.517^{* * *}$ & .1 & $-.449^{* * *}$ & .092 & $-.692^{* * *}$ & $.15^{2}$ & .134 & .131 \\
\hline Catholic & & & .067 & .084 & -.174 & .147 & $.651^{* * *}$ & .127 \\
\hline Mainline Pro & -.067 & .084 & & & -.242 & .142 & $.583^{* * *}$ & .119 \\
\hline Evangelical & .174 & .147 & .242 & .142 & & & $.826^{* * *}$ & .17 \\
\hline Funda-Pente & $-.651^{* * *}$ & .127 & $-.583^{* * *}$ & .119 & $-.826^{* * *}$ & .17 & & \\
\hline
\end{tabular}

${ }^{*} \mathrm{p}<.05 .{ }^{* *} \mathrm{p}<.01 .{ }^{* * *} \mathrm{p}<.001$.

TABLE 4 Multiple regression estimates of trust in $2006(n=8,497)$

\begin{tabular}{|c|c|c|c|c|c|c|c|c|}
\hline & \multicolumn{2}{|l|}{ Model 1} & \multicolumn{2}{|l|}{ Model 2} & \multicolumn{2}{|l|}{ Model 3} & \multicolumn{2}{|l|}{ Model 4} \\
\hline & b & SE & $\mathbf{b}$ & SE & $\mathbf{b}$ & SE & $\mathbf{b}$ & SE \\
\hline \multicolumn{9}{|l|}{ Control Var. } \\
\hline Age & $5 \cdot 788^{* * *}$ & 1.733 & $5.892^{* * *}$ & 1.732 & $5 \cdot 791^{* * *}$ & 1.733 & $5.899^{* * *}$ & 1.733 \\
\hline Age Squared & $-3 \cdot 5^{26^{*}}$ & 1.626 & $-3 \cdot 747^{*}$ & 1.626 & $-3 \cdot 529^{*}$ & 1.625 & $-3.631^{*}$ & 1.626 \\
\hline Female & $.273^{* *}$ & .1 & $.269^{* *}$ & .099 & $.273^{* *}$ & .1 & $.272^{* *}$ & .099 \\
\hline Income & $.065^{* * *}$ & .013 & $.065^{* * *}$ & .013 & $.065^{* * *}$ & .013 & $.064^{* * *}$ & .013 \\
\hline Education & $.181^{* * *}$ & .017 & $.179^{* * *}$ & .017 & $.181^{* * *}$ & .017 & $.179^{* * *}$ & .017 \\
\hline White & $2.444^{* * *}$ & .136 & $2.458^{* * *}$ & .135 & $2.445^{* * *}$ & .135 & $2.428^{* * *}$ & .136 \\
\hline Northeast & $.256^{*}$ & .12 & $.298^{*}$ & .118 & $.256^{*}$ & .117 & $.238^{*}$ & .117 \\
\hline Married & $.433^{* * *}$ & .107 & $.425^{* * *}$ & .106 & $.433^{* * *}$ & .106 & $.43^{* * *}$ & .106 \\
\hline Employed & $1.43^{6 * *}$ & .115 & $1.432^{* * *}$ & .115 & $1.436^{* * *}$ & .115 & $1.435^{* * *}$ & .115 \\
\hline Church Member & $\cdot 359^{* *}$ & .132 & $\cdot 349^{* *}$ & .132 & $.359^{* *}$ & .132 & $.359^{* *}$ & .132 \\
\hline Frequency & $.011^{* * *}$ & .002 & $.011^{* * *}$ & .002 & $.011^{* * *}$ & .002 & $.011^{* * *}$ & .002 \\
\hline
\end{tabular}

\section{Independent Var.}

Catholic

.003

.116

Mainline Pro

Evangelical

$.298^{* *}$

.099

Funda-Pente

$-.015 \quad .154$




\begin{tabular}{|c|c|c|c|c|c|c|c|c|}
\hline & Model 1 & & Model 2 & & Model 3 & & Model 4 & \\
\hline & b & SE & b & SE & b & SE & b & SE \\
\hline Constant & $8.142^{* * *}$ & .496 & $8.046^{* * *}$ & .497 & $8.143^{* * *}$ & .496 & $8.191^{* * *}$ & .497 \\
\hline Adj. $R^{2}$ & .1093 & & .1102 & & .1093 & & 1096 & \\
\hline Predicted Value & 18.6 & & 18.81 & & 18.59 & & 18.3 & \\
\hline Diff (2000-2006) & .606 & & .801 & & $\cdot 376$ & & .922 & \\
\hline
\end{tabular}

${ }^{*} \mathrm{p}<.05 .{ }^{* *} \mathrm{p}<.01 .{ }^{* * *} \mathrm{p}<.001$.

TABLE $4 \quad$ Multiple regression estimates of trust in 2006 (cont.)

\begin{tabular}{|c|c|c|c|c|c|c|c|c|}
\hline & Model 5 & & Model 6 & & Model 7 & & Model 8 & \\
\hline & $\mathbf{b}$ & SE & $\mathbf{b}$ & SE & b & SE & $\mathbf{b}$ & SE \\
\hline Other Religion & -.259 & .154 & $-.435^{* *}$ & .14 & -.242 & .187 & .023 & .196 \\
\hline Catholic & & & -.176 & .128 & .016 & .178 & .282 & .19 \\
\hline Mainline Pro & .176 & .128 & & & .193 & .165 & $.459 * *$ & .175 \\
\hline Evangelical & -.016 & .178 & -.193 & .165 & & & .265 & .215 \\
\hline Funda-Pente & -.282 & .19 & $-.459^{* *}$ & .175 & -.265 & .215 & & \\
\hline
\end{tabular}

${ }^{*} \mathrm{p}<.05 .{ }^{* *} \mathrm{p}<.01 .{ }^{* * *} \mathrm{p}<.001$.

In regards to the civic engagement behavior, Models 1 through 4 of Table 5 show that in 2000, while being a member of Mainline Protestant tradition significantly and positively affected one's participation in civic activities, being a member of Fundamentalist-Pentecostal tradition significantly and negatively affected one's participation in civic activities. Being a member of Catholic or Evangelical tradition did not significantly affect one's participation in civic activities. The predicted values for the level of participation in civic activities of the religious traditions show that Mainline Protestants were the most participating individuals in civic activities, followed by Catholics, Evangelicals, and Fundamentalists-Pentecostals. Despite that, the differences between Mainline Protestants, Catholics, and Evangelicals were not significant, as can be seen in Models 5 through 8 of Table 5 . Fundamentalists-Pentecostals significantly participated less than the members of Mainline Protestant and Catholic tradition, but not the Evangelical tradition. 
TABLE 5 Negative binomial regression estimates of civic engagement in $2000(n=19,330)$

\begin{tabular}{|c|c|c|c|c|c|c|c|c|}
\hline & & & Model 2 & & Model 3 & & Model 4 & \\
\hline & $\mathbf{b}$ & $S E$ & $\mathbf{b}$ & $S E$ & $\mathbf{b}$ & SE & b & SE \\
\hline \multicolumn{9}{|l|}{ Control Var. } \\
\hline Age & $1.354^{* * *}$ & .206 & $1.35^{* * *}$ & .206 & $1.366^{* * *}$ & .206 & $1.388^{* * *}$ & .206 \\
\hline Age Squared & $-1.296^{* * *}$ & .21 & $-1.302^{* * *}$ & .21 & $-1.305^{* * *}$ & .21 & $-1.328^{* * *}$ & .21 \\
\hline Female & .02 & .011 & .019 & .011 & .021 & .011 & .02 & .011 \\
\hline Income & $.022^{* * *}$ & .001 & $.022^{* * *}$ & .001 & $.022^{* * *}$ & .001 & $.022^{* * *}$ & .001 \\
\hline Education & $.069 * * *$ & .002 & $.069^{* * *}$ & .002 & $.069 * * *$ & .002 & $.068^{* * *}$ & .002 \\
\hline White & $-.123^{* * *}$ & .014 & $-.125^{* * *}$ & .014 & $-.125^{* * *}$ & .014 & $-.129^{* * *}$ & .014 \\
\hline Northeast & $-.052^{* * *}$ & .016 & $-.053^{* * *}$ & .016 & $-.055^{* * *}$ & .016 & $-.057^{* * *}$ & .016 \\
\hline Married & -.011 & .012 & -.012 & .012 & -.011 & .012 & -.01 & .012 \\
\hline Employed & $.045^{* *}$ & .014 & $.045^{* *}$ & .014 & $.045^{* *}$ & .014 & $.045^{* *}$ & .014 \\
\hline Church Member & $.19^{* * *}$ & .015 & $.189^{* * *}$ & .015 & $.188 * * *$ & .015 & $.189^{* * *}$ & .015 \\
\hline Frequency & $.004^{* * *}$ & .0003 & $.004^{* * *}$ & .0003 & $.004^{* * *}$ & .0003 & $.004^{* * *}$ & .0003 \\
\hline \multicolumn{9}{|l|}{ Independent Var. } \\
\hline Catholic & -.016 & .013 & & & & & & \\
\hline Mainline Pro & & & $.024^{*}$ & .011 & & & & \\
\hline Evangelical & & & & & -.029 & .023 & & \\
\hline Funda-Pente & & & & & & & $-.061^{* *}$ & .019 \\
\hline Constant & $-.55^{* * *}$ & .052 & $-.559^{* * *}$ & .052 & $-.554^{* * *}$ & .052 & $-.544^{* * *}$ & .052 \\
\hline Log Likelihood & $-41,331$ & & $-41,330$ & & $-41,331$ & & $-41,327$ & \\
\hline Predicted Value & 3.01 & & 3.086 & & 2.956 & & $2.85^{2}$ & \\
\hline
\end{tabular}

${ }^{*} \mathrm{p}<.05 .{ }^{* *} \mathrm{p}<.01 .{ }^{* * *} \mathrm{p}<.001$. 
TABLE 5 Negative binomial regression estimates of civic engagement in 2000 (cont.)

\begin{tabular}{|c|c|c|c|c|c|c|c|c|}
\hline & Model 5 & & Model 6 & & Model 7 & & Model 8 & \\
\hline & b & SE & b & SE & $\mathbf{b}$ & SE & b & SE \\
\hline Other Religion & .032 & .017 & .006 & .015 & .048 & .026 & $.076^{* * *}$ & .023 \\
\hline Catholic & & & -.026 & .014 & .015 & .025 & $.043^{*}$ & .022 \\
\hline Mainline Pro & .026 & .014 & & & .042 & .024 & $.069^{* * *}$ & .021 \\
\hline Evangelical & -.015 & .025 & -.042 & .024 & & & .027 & .029 \\
\hline Funda-Pente & $-.043^{*}$ & .022 & $-.069 * * *$ & .021 & -.027 & .029 & & \\
\hline
\end{tabular}

${ }^{*} \mathrm{p}<.05 .{ }^{* *} \mathrm{p}<.01 .{ }^{* * * *} \mathrm{p}<.001$.

As in 2000, in 2006, being a member of Mainline Protestant tradition significantly and positively affected one's participation in civic activities, while being a member of Fundamentalist-Pentecostal tradition significantly and negatively affected one's participation, as can be seen in Models 1 through 4 of Table 6. The predicted values indicate that the participation rates of the members of all the religious traditions decreased from 2000 to 2006, and this decrease was the most for Fundamentalists-Pentecostals with .812 units. In addition, as shown in Models 5 through 8 of Table 6, Fundamentalists-Pentecostals significantly participated in civic activities less than the members of all the other religious traditions. Also, Evangelicals significantly participated less than Mainline Protestants. Catholics and Mainline Protestants shared similar characteristics in their participation in civic activities.

TABLE 6 Negative binomial regression estimates of civic engagement in $2006(n=8,498)$

\begin{tabular}{llllllllll}
\hline & $\begin{array}{l}\text { Model 1 } \\
\text { b }\end{array}$ & \multicolumn{3}{c}{$\begin{array}{l}\text { Model 2 } \\
\text { b }\end{array}$} & SE & $\begin{array}{l}\text { Model 3 } \\
\text { b }\end{array}$ & SE & $\begin{array}{l}\text { Model 4 } \\
\text { b }\end{array}$ & SE \\
\hline Control Var. & & & & & & & & \\
$\quad$ Age & .548 & .425 & $-.53^{2}$ & .425 & -.544 & .425 & -.499 & .425 \\
Age Squared & .571 & .399 & .537 & .399 & .568 & .399 & .528 & .399 \\
Female & $.049^{*}$ & .024 & $.049^{*}$ & .024 & $.051^{*}$ & .024 & $.05^{*}$ & .024 \\
Income & $.025^{* * *}$ & .003 & $.025^{* * *}$ & .003 & $.025^{* * *}$ & .003 & $.025^{* * *}$ & .003 \\
Education & $.07^{* * *}$ & .004 & $.07^{* * *}$ & .004 & $.07^{* * *}$ & .004 & $.069^{* * *}$ & .004
\end{tabular}


TABLE $6 \quad$ Negative binomial regression estimates of civic engagement in 2006 (cont.)

\begin{tabular}{|c|c|c|c|c|c|c|c|c|}
\hline & Model 1 & & Model 2 & & Model 3 & & Model 4 & \\
\hline & b & SE & $\mathbf{b}$ & SE & $\mathbf{b}$ & SE & b & SE \\
\hline White & $-.199^{* * *}$ & .032 & $-.199^{* * *}$ & .032 & $-.201^{* * *}$ & .032 & $-.211^{* * *}$ & .032 \\
\hline Northeast & $-.05^{1}$ & .029 & -.048 & .029 & $-.057^{*}$ & .029 & $-.065^{*}$ & .029 \\
\hline Married & .02 & .026 & .02 & .026 & .022 & .026 & .023 & .026 \\
\hline Employed & $.104^{* * *}$ & .028 & $.104^{* * *}$ & .028 & $.105^{* * *}$ & .028 & $.104^{* * * *}$ & .028 \\
\hline Church Member & $.185^{* * *}$ & .033 & $.181^{* * *}$ & .033 & $.181 * * *$ & .033 & $.183^{* * *}$ & .033 \\
\hline Frequency & $.003^{* * *}$ & .0006 & $.003^{* * *}$ & .0006 & $.003^{* * *}$ & .0006 & $.004^{* * *}$ & .0006 \\
\hline \multicolumn{9}{|l|}{ Independent Var. } \\
\hline Catholic & -.019 & .028 & & & & & & \\
\hline Mainline Pro & & & $.049^{*}$ & .024 & & & & \\
\hline Evangelical & & & & & -.055 & .038 & & \\
\hline Funda-Pente & & & & & & & $-.171^{* * * *}$ & .041 \\
\hline Constant & $-.386^{* * *}$ & .12 & $-.403^{* * * *}$ & .121 & $-.383^{* *}$ & .12 & $-.363^{* *}$ & .12 \\
\hline Log Likelihood & $-17,326$ & & $-17,324$ & & $-17,325$ & & $-17,318$ & \\
\hline Predicted Value & 2.307 & & 2.425 & & 2.221 & & 2.04 & \\
\hline Diff (2000-2006) & -.703 & & -.661 & & -.735 & & -.812 & \\
\hline
\end{tabular}

${ }^{*} \mathrm{p}<.05 .{ }^{* *} \mathrm{p}<.01 .{ }^{* * *} \mathrm{p}<.001$.

TABLE $6 \quad$ Negative binomial regression estimates of civic engagement in 2006 (cont.)

\begin{tabular}{|c|c|c|c|c|c|c|c|c|}
\hline & Model 5 & & Model 6 & & Model 7 & & Model 8 & \\
\hline & b & SE & $\mathbf{b}$ & SE & b & SE & b & SE \\
\hline Other Religion & $.072 *$ & .037 & .031 & .034 & $.109 *$ & .045 & $.215^{* * *}$ & .048 \\
\hline Catholic & & & -.041 & .031 & .037 & .043 & $.142^{* *}$ & .047 \\
\hline Mainline Pro & .041 & .031 & & & $.078^{*}$ & .04 & $.183^{* * *}$ & .043 \\
\hline Evangelical & -.037 & .043 & $-.078^{*}$ & .04 & & & $.105^{*}$ & .053 \\
\hline Funda-Pente & $-.142^{* *}$ & .047 & $-.183^{* * *}$ & .043 & $-.105^{*}$ & .053 & & \\
\hline
\end{tabular}

${ }^{*} \mathrm{p}<.05 .{ }^{* *} \mathrm{p}<.01 .{ }^{* * *} \mathrm{p}<.001$. 
In sum, regarding the first research question, only trust attitude significantly increased from 2000 to 2006 and this shows that the immediate increases in trust after $9 / 11$ led to long-lived increases in trust. However, the immediate increases in civic consciousness after 9/11 did not lead to long-term behaviors and therefore I could not find long-lived increases in the level of civic engagement in American society from 2000 to 2006. On the contrary, the level of civic engagement significantly decreased during this period.

In regards to the second research question, members of religious traditions behaved differently in 2000 and 2006, depending on their worldviews affected by their religious orientations. In general, Mainline Protestants appeared as the most trusting and frequently participating individuals, followed by Catholics and Evangelicals. These three religious traditions basically showed similar trends in terms of trust attitude and civic engagement behavior in both years. Fundamentalists-Pentecostals, on the other hand, trusted the least in 2000; however, they showed the largest increase in trust from 2000 to 2006. Also, they participated in civic activities the least compared to the other three religious groups and thus showed their reluctance in active civic life.

\section{5}

\section{Discussions and Conclusion}

The aim of this study was to explore (1) whether the level of social capital in American society, conceptualized as trust and civic engagement, changed following $9 / 11$, considering the context of the declining trend of social capital since 196os, and (2) the role of religious traditions - Conservative Protestantism, Mainline Protestantism, and Catholicism - in such change through a secondary analysis of the 2000 Social Capital Community Benchmark Survey and the 2006 Social Capital Community Survey.

The findings of this study showed that the immediate increases in social capital in the form of civic engagement behavior following 9/11 had been short-lived and quickly faded away in a short time. However, increases in social capital in the form of trust attitude had been long-lived and persisted with an increasing trend by 2006. This provides evidence to Putnam's (2002) attitude-behavior dilemma, which indicates that while 9/11 was an opportunity for civic renewal against the long-term civic decline in American society since 1960 s, the intentions to do good for the others and the society and interest in political and civic activities that quickly arose after 9/11 did not lead to long-term behaviors. In other words, attitudes of trust and civic mindedness did not lead to long-term civic engagement behavior. On the other hand, trust attitude had been long-lived and persisted for a longer time (see Table 2). 
Thus, it can be argued that the reviving effects of $9 / 11$ on American society provoked in a long-term increase in trust attitude. While it cannot be claimed statistically that $9 / 11$ directly caused this, $9 / 11$ was the most likely reason that reversed the long-term decline in trust in American society since 196os. On the other hand, the long-term decline in civic engagement paused only briefly after 9/11 and persisted despite the restorative energy of 9/11 by 2006 . In Putnam's words, "Americans have been [still] dropping out in droves, not merely from political life, but from organized community life more generally" (2000: 64).

In this context, one can ask: (1) why should we consider $9 / 11$ as the most likely reason that reversed the long-term decline in social capital in American society, and if we should, (2) why did 9/11 work as a full stop for the decline in trust and a brief pause for the decline in civic engagement in the last quarter of the 2oth century? According to Beyerlein and Sikkink (2008), 9/11 was different for Americans as a disaster than weather-related disasters. Although the sense of identification was likely to be difficult to create in some weather-related disasters, 9/11 provided a unique setting, a collective identity, for creating an idealization of Americanness and generating empathy among Americans. This was provided by the emotional energy that existed after $9 / 11$ (Beyerlein and Sikkink 2008). Related to this, Collins (2004: 2) states that:

Occasions that combine a high degree of mutual focus of attention, that is, a high degree of intersubjectivity, together with a high degree of emotional entrainment - through bodily synchronization, mutual stimulation/arousal of participants' nervous systems - result in feelings of membership that are attached to cognitive symbols; and result also in the emotional energy of individual participants, giving them feelings of confidence, enthusiasm, and desire for action in what they consider a morally proper path. These moments of high degree of ritual intensity are high points of experience. They are high points of collective experience, the key moments of history, the times when significant things happen. These are moments that tear up old social structures or leave them behind, and shape new social structures ... These are moments like the national mobilization in the United States following September 11, 2001.

In the following days of $9 / 11$, the images of the burning and collapsing towers were repetitively displayed on television and in news photos by the media. These images were easily transformed into symbols, and those symbols crystalized a group identity, "Americans," that encompassed everyone who called himself/herself as an American (Collins 2004). Not only the image of the burning 
and collapsing towers, but also the other images were reified as symbols. These symbols have led the Americans to show significant changes in civic life, political consciousness and engagement, trust in government, police, and one another, and participation in community projects and political meetings after 9/11. These symbols have represented their sentiments after the tragic event (Collins 2004). However, as days passed, those symbols and images began to fade away from people's minds. Therefore, subsequently, sentiments that created all those changes in civic life immediately after $9 / 11$ also began to fade away. As Collins (2004: 39) states, "sentiments fade out over a period of time if they are not resuscitated by another experience of collective effervescence." Therefore, over a period of time, from 2001 to 2006, those sentiments, which converted attitudes into behaviors immediately after $9 / 11$, such as trust and civic mindedness into civic engagement, under the influence of the symbols and images created by the media, lost their energy and faded out. This might be a reasonable explanation why the immediate increase in civic engagement behavior had been short-lived following $9 / 11$ and continued to decline as it did since 1960 s. As an attitude, trust did not follow the same pattern since attitudes do not easily fade out because of their relatively enduring structure compared to behaviors (Hogg and Vaughan 2005).

As a result, while Putnam (2000: 136-137) argues that people who trust their fellow citizens participate more often in community organizations and display many other forms of civic virtue, findings of the current study contradict Putnam's statements. This contradiction might have existed due to the idiosyncratic characteristic of 9/11 as an important and life-changing event for American society and therefore needs further research to understand.

In addition to the changing trend of social capital following $9 / 11$, another important aspect of this study was the changing effects of religious traditions on their members' levels of social capital. It may firstly be concluded that in terms of trust attitude, all religious traditions significantly affected their members' levels of trust - Mainline Protestant, Catholic, and Evangelical traditions positively, Fundamentalist-Pentecostal tradition negatively (see Models 1-4 of Tables 3). However, this trend changed in 2006 and none of the religious traditions, except for Mainline Protestantism, significantly affected its members' levels of trust (see Models 1-4 of Table 4). Therefore, it can be argued that from 2000 to 2006 the gaps between the levels of trust of the members of different religious traditions faded out. This could also be seen through the disappearing significant differences between religious traditions (see Models $5-8$ of Tables 3 and 4). In 2000, Fundamentalists-Pentecostals significantly trusted less than the other three religious traditions; however, in 2006, they significantly trusted less only than Mainline Protestants. The members of all religious traditions 
increased their levels of trust from 2000 to 2006; however, FundamentalistsPentecostals increased the most and this was the major reason for the closing trust gap among religious traditions.

It can be posited that in 2000 Mainline Protestants, Catholics, and Evangelicals shared similar characteristics in terms of trust and differed from Fundamentalists-Pentecostals. However, through the likely positive effect of 9/11, this separation between the members of the two groups of religious traditions - Mainline Protestants, Catholics, and Evangelicals on the one side and Fundamentalists-Pentecostals on the other side - disappeared in 2006. The unifying effects of $9 / 11$ brought all the people from different religious traditions together and wiped out the doubts and differences among them. Thus, they increased their levels of trust to one another and struck an attitude towards the threats together.

Regarding the civic engagement behavior, Catholics and Mainline Protestants shared similar characteristics in both 2000 and 2006, differed from Fundamentalists-Pentecostals, and significantly participated in civic activities more than them. Members of all religious traditions reduced their levels of participation in civic activities, with Fundamentalists-Pentecostals having the largest decline. Even though the members of all the religious traditions increased their levels of trust and achieved an attitudinal success, this did not lead to behavioral success. Interestingly, the largest increase in trust belonged to Fundamentalists-Pentecostals and it led to the largest decline in civic engagement. In this respect, further research is needed to understand why there was an inconsistency between the trust attitude and civic engagement behavior, as can be seen among the members of the religious traditions. Also, future research might consider focusing on the relationship between the other forms of attitudes and behaviors such as political interest and political participation to better understand the inconsistency between attitudes and behaviors and the effect of $9 / 11$ on social capital in American society.

Overall, these findings indicate that the worldviews of religious traditions significantly affect their members' attitudes and behaviors towards others. The worldly-oriented Mainline Protestant and Catholic traditions differed from the otherworldly oriented Fundamentalist-Pentecostal tradition in terms of active civic life and social trust. Despite being a Conservative Protestant tradition, the Evangelical tradition shared similar subculture characteristics with Mainline Protestant and Catholic traditions and differed from the FundamentalistPentecostal tradition. While the significant differences in trust between the worldly-oriented religious traditions and the otherworldly oriented religious tradition faded out from 2000 to 2006 , this attitudinal change did not lead to 
behavioral change. The worldly religious orientation encourages people to be active in civic life; however, since 1960 s there has been a decline in active civic life not only within the Fundamentalist-Pentecostal tradition but also within the other religious traditions. This trend only reversed immediately after $9 / 11$, but this was the case for only a short while. Even though the behavioral success achieved immediately after $9 / 11$ with civic engagement could not be maintained longer, the attitudinal success in trust could be maintained. Thus, this study showed that in the context of a declining trend of social capital since the first half of the 2oth century, there had been important changes in American society and within religious groups in terms of trust from 2000 to 2006. It can be argued that while the decline in civic engagement during this period followed the ongoing decline since 1960s, the increase in trust reversed the ongoing decline and provided a hope for a more united and integrated society. It is assumed that despite impossible to prove statistically, this important reversal resulted from the 9/11 terrorist attacks, which, as Putnam (2000) argued, was an opportunity for people to come together, get rid of differences, and achieve this kind of a success.

This paper makes three major contributions to the literature. This paper gives us the opportunity; (1) to outline the trend of social capital, conceptualized as trust and civic engagement, in American society from 2000 to 2006; (2) to evaluate the possible effect of $9 / 11$ on trust attitude and civic engagement behavior on the basis of religion; and (3) to examine how religious traditions responded to the destructive effects of $9 / 11$ by means of social trust and civic engagement.

One important limitation of this study is that while this study attempts to analyze the effect of $9 / 11$ on the trend of social capital in American society, I could not include a 9/11-effect variable into the analysis due to data restrictions. Therefore, this study presents its findings with the assumption that during the period between 2001 and 2006, 9/11 maintained its influence on American society. In addition, because of the varying availability of civic venues by urbanicity, I wanted to include a geographic location in the analysis. However, due to lack of consistency between the 2000 SCCBS and the 2006 sCCs, a "metropolitan status" variable could not be included into the analysis. These limitations may have biased the current results.

This study is expected to cast fresh light on the relationship between religion and social capital by focusing on the diverse perspectives of religious traditions in American society in the context of 9/11. It is expected that the findings of this paper provide important information for the policymakers who are expected to be aware of the possible social consequences of the crisis 
like the one that occurred in the aftermath of $9 / 11$ for the wellbeing of society. Also, it is expected that the findings emphasize the importance of the diversities of religious traditions on the functioning of society.

\section{References}

Alexander, Jeffrey C. 2004. From the Depths of Despair: Performance, Counterperformance, and September 11. Sociological Theory 22(1): 88-105.

Beyerlein, Kraig and John R. Hipp. 2006. From Pews to Participation: The Effect of Congregation Activity and Context on Bridging Civic Engagement. Social Problems 53(1): 97-107.

Beyerlein, Kraig and David Sikkink. 2008. Sorrow and Solidarity: Why Americans Volunteered for 9/11 Relief Efforts. Social Problems 55(2): 190-215.

Blanchard, Troy C. 2007. Conservative Protestant Congregations and Racial Residential Segregation: Evaluating the Closed Community Thesis in Metropolitan and Nonmetropolitan Counties. American Sociological Review 72(3): 416-433.

Blanchard, Troy C., John Bartkowski, Todd L. Matthews, and Kent R. Kerley. 2008. Faith, Morality, and Mortality: The Ecological Impact of Religion on Population Health. Social Forces 86(4): 1591-1620.

Cimino, Richard. 2005. No God in Common: American Evangelical Discourse on Islam After 9/11. Review of Religious Research 47(2): 162-174.

Collier, Paul. 2002. Social Capital and Poverty: A Microeconomic Perspective. In The Role of Social Capital in Development, ed. Thierry Van Bastelaer, 19-41. Melbourne: Cambridge University Press.

Collins, Randall. 2004. Interactive Ritual Chains. New Jersey: Princeton University Press. Cox, Eva, and Peter Caldwell. 200o. Making Policy Social. Social Capital and Public Policy in Australia, Australian Institute of Family Studies, Melbourne 43-73.

Edgell, Penny, Joseph Gerteis, and Douglas Hartmann. 2008. Atheists As Other: Moral Boundaries and Cultural Membership in American Society. American Sociological Review 71(2): 211-234.

Ferlander, Sara. 2007. The Importance of Different Forms of Social Capital for Health. Acta Sociologica 50(2): 115-128.

Fukuyama, Francis. 2001. Social Capital, Civil Society, and Development. Third World Quarterly 22(1): 7-20.

Glaeser, Edward L., David I. Laibson, Jose A. Scheinkman, and Christine L. Soutter. 2000. Measuring Trust. Quarterly Journal of Economics 811-846.

Henshall, Ian and Rowland Morgan. 2005. 9/n Revealed: The Unanswered Questions. New York: Carroll \& Graf Publishers.

Hilbe, J. M. 2011. Negative Binomial Regression, 2nd Edition. Cambridge: Cambridge University Press. 
Hodgson, Peter C. 2005. Christian Theology in An Age of Terror. Network News 25(2): 4-7.

Hogg, M. and G. Vaughan. 2005. Social Psychology, 4th Edition. London: Prentice-Hall. Huntington, Samuel P. 1993. The Clash of Civilizations? Foreign Affairs 72(3): 22-49.

Johnson, Stephen D. 2006. Religion and Anti-Islamic Attitudes. Review of Religious Research 48(1): 5-16.

Kaya, Ilhan. 2007. Religion as a Site of Boundary Construction: Islam and the Integration of the Turkish Americans in the United States. Alternatives: Turkish Journal of International Relations 6(1/2): 139-155.

Klandermans, Bert, Jojanneke van der Toorn, and Jacquelien van Stekelenburg. 2008. Embeddedness and Identity: How Immigrants Turn Grievances into Action. American Sociological Review 73(8): 992-1012.

Kolankiewicz, George. 1996. Social Capital and Social Change. British Journal of Sociology 427-441.

Land, Kenneth C., Patricia L. McCall, and Daniel S. Nagin. 1998. A Comparison of Poisson, Negative Binomial, and Semiparametric Mixed Poisson Regression Models with Empirical Applications to Criminal Careers Data. Sociological Methods Research 24: 387-442.

Lappe, Frances Moore and Paul Martin Du Bois. 1997. Building Social Capital Without Looking Backward. National Civic Review 86(2):119-128.

Lehrer, E. L. 2004. Religion as a Determinant of Economic and Demographic Behavior in the United States. Population and Development Review 30(4): 707-726.

Lin, Nan. 2001. Social Capital: A Theory of Social Structure and Action. New York, NY: Cambridge University Press.

Lochner, Kimberly A., Ichiro Kawachi, Robert T. Brennan, and Stephen L. Buka. 2003. Social Capital and Neighborhood Mortality Rates in Chicago. Social Science \& Medicine 56(8): 1797-1805.

Massengill, Rebekah P. 2008. Educational Attainment and Cohort Change Among Conservative Protestants, 1972-2004. Journal for the Scientific Study of Religion 47(4): $545-562$.

Owen, Stephen S. And Kenneth Wagner. 20o6. Explaning School Corporal Punishment: Evangelical Protestantism and Social Capital in a Path Model. SocialJustice Research 19(4): 471-499.

Portes, Alejandro and Patricia Landolt. 1996. The Downside of Social Capital. American Prospect 26(3):18-21.

Putnam, Robert D. 1995. Bowling Alone: America's Declining Social Capital. Journal of Democracy 6(1): 65-78.

Putnam, Robert D. 2000. Bowling Alone: The Collapse and Revival of American Community. New York: Simon and Schuster.

Putnam, Robert D. 2002. Bowling Together. American Prospect 13(3): 20-22. 
Putnam, Robert D. 2003. Bowling Together. In United We Serve, ed. E. J. Dionne Jr., Kayla Meltzer Drogosz, and Robert E. Litan, 13-19. Washington: Brookings Institution Press.

Rhodes, Jeremy. 2012. The Ties that Divide: Bonding Social Capital, Religious Friendship Networks, and Political Tolerance Among Evangelicals. Sociological Inquiry 8292): 163-186.

Sander, Thomas H. And Robert D. Putnam. 2010. Still Bowling Alone? The Post 9/11 Split. Journal of Democracy 21(1): 9-16.

Schmierbach, Mike, Michael P. Boyle, and Douglas M. McLeod. 2005. Civic Attachment in the Aftermath of September 11. Mass Communication and Society 8(4):323-346.

Skrabski, Árpad, Maria Kopp, and Ichiro Kawachi. 2003. Social Capital in a Changing Society: Cross Sectional Associations With Middle Aged Female and Male Mortality Rates. Journal of Epidemiology and Community Health 57(2): 114-119.

Staveren, Irene Van. 2003. Beyond Social Capital in Poverty Research. Journal of Economic Issues 37(2): 415-423.

Steensland, Brian, Jerry Z. Park, Mark D. Regnerus, Lynn D. Robinson, W. Bradford Wilcox, and Robert D. Woodberry. 2000. The Measure of American Religion: Toward Improving the State of the Art. Social Forces 79(1): 291-318.

Uslaner, Eric M. 2002. Religion and Civic Engagement in Canada and the United States. Journal for the Scientific Study of Religion 41(2): 239-254.

Vaaler, M. L., C. G. Ellison, and D. A. Powers. 2009. Religious Influences on the Risk of Marital Dissolution. Journal of Marriage and Family 71: 917-934.

Veenstra, Gerry. 2002. Social Capital and Health (Plus Wealth, Income Inequality, and Regional Health Governance). Social Science \& Medicine 54(6): 849-868.

Verba, Sidney, Kay Lehman Schlozman, and Henry E. Brandy. 1997. The Big Tilt: Participatory Inequality in America. American Prospect 32(3): 74-81.

Warde, Alan, Gindo Tampubolon, Brian Longhurst, Kathryn Ray, Mike Savage, and Mark Tomlinson. 2003. Trends in Social Capital: Membership of Associations in Great Britain, 1991-98. British Journal of Political Science 33(3): 515-525.

Woodberry, RobertD. And Christian S. Smith. 1998. Fundamentalism et al.: Conservative Protestants in America. Annual Review of Sociology 24(1): 25-56.

Wollebaek, Dag and Per Selle. 2003. The Importance of Passive Membership for Social Capital Formation. In Generating Social Capital, ed. Dag Wollebaek and Per Selle, 67-88. Palgrave Macmillan, us.

Wuthnow, Robert. 2002. Religious Involvement and Status-Bridging Social Capital. Journal for the Scientific Study of Religion 41(4): 669-684.

Yeary, Karen, Hye-cheon Kim, Songthip Qunpraseuth, Page Moore, Zoran Bursac, and Paul Greene. 2012. Religion, Social Capital, and Health. Review of Religious Research. Zhao, Yandong. 2002. Measuring the Social Capital of Laid-Off Chinese Workers. Current Sociology 50(4): 555-571. 


\section{Appendix}

\section{Items Used to Operationalize the Dependent Variables: Trust}

(Responses are "trust them a lot" "trust them some" "trust them only a little" and "trust them not at all")

- How much you can trust people in your neighborhood?

- How much you can trust people you work with?

- How much you can trust people who work in the stores where you shop?

- How much you can trust the police in your local community?

- How much you can trust white people?

- How much you can trust African Americans or Blacks?

- How much you can trust Asian people?

- How much you can trust Hispanics or Latinos?

\section{Items Used to Operationalize the Dependent Variables: Civic Engagement}

(Responses are "yes" or "no".)

- Have you worked on a community project in the past 12 months?

- In the past 12 months, have you participated in a sports club, league, or outdoor activity club?

- In the past 12 months, have you participated in a youth organization like a sports league, 4 -H club, etc.?

- In the past 12 months, have you participated in parent association, like the PTA or РTO, or other school support or service group?

- In the past 12 months, have you participated in a neighborhood association?

- In the past 12 months, have you participated in a seniors group?

- In the past 12 months, have you participated in charity or social welfare organization?

- In the past 12 months, have you participated in a professional, trade, farm or business association?

- In the past 12 months, have you participated in a service or fraternal organization?

- In the past 12 months, have you participated in an ethnic, nationality, or civil rights organization?

- In the past 12 months, have you participated in a literary, art, musical, dancing, or singing group?

- In the past 12 months, have you participated in any other hobby, investment, or garden club or society?

- In the past 12 months, have you participated in a self-help program for people with specific illnesses, disabilities, problems, or addictions, or for their families? 